\title{
FUNCTIONALITY OF AQUACULTURAL TECHNIQUES IN DELTA STATE, NIGERIA: ADOPTION APPROACHES
}

\author{
Oghenero Joseph OVHARHE ${ }^{1 *}$, Oster NWACHI ${ }^{2}$, Victory OMOROGIE ${ }^{1}$ \\ ${ }^{1}$ Department of Agricultural Economics and Extension, Delta State University, Asaba Campus, Asaba, Delta State, Nigeria \\ ${ }^{2}$ Department of Animal Science and Fisheries Delta State University, Asaba Campus, Asaba, Delta State, Nigeria
}

\begin{abstract}
Appropriate adoption techniques in aquaculture contribute to food security. The study appraised the functionality of aquacultural techniques in Oshimili South Local Government Area of Delta State, Nigeria using adoption approaches. The objectives were to ascertain the level of adoption management techniques, examine the pond types of adoption, assess fish farmers' technological needs and identify constraints affecting adoption. A quota sampling technique was used to select respondents to acquire a sample size of 82 who were administered with questionnaire to elicit information. Data obtained were analyzed statistically. Results revealed that respondents were male (83\%) with mean age of 44 years, mean household size 5 persons, married (65\%) and had mean farming experience of 7 years. Majority (92\%) had annual extension visit. Majority (78\%) adopted earthen pond management techniques with high adoption score $=5.4$. Again, majority $(88 \%)$ adopted earthen pond over plastic $(79 \%)$, concrete $(71 \%)$ and wooden pond $(59 \%)$. Majority (90.2\%) indicated that integrated techniques were their prioritized need and respondents (80.5\%) pointed out that high feed cost was their most serious constraint (mean $=3.06$ ). It was concluded that there was a high adoption rate of aquacultural techniques in the study area. It is recommended that extension visits should be monthly and training on integrated techniques, feed formulation among others is needed.
\end{abstract}

Keywords: Adoption, Aquaculture, Extension, Farming, Fish farmers, Techniques

*Corresponding author: Department of Agricultural Economics and Extension, Delta State University, Asaba Campus, Asaba, Delta State, Nigeria E mail: drovharhe.oghenero@gmail.com (0. OGHENERO)

Oghenero Joseph OVHARHE (iD) https://orcid.org/0000-0003-0732-2793

Oster NWACHI (iD) https://orcid.org/0000-0001-9828-2330

Victory OMOROGIE (iD) https://orcid.org/0000-0003-1475-3823

Received: June 26, 2020

Accepted: December 27, 2020

Cite as: Ovharne OJ, Nwachi O, Omorogie V. 2021. Functionality of aquacultural techniques in Delta State, Nigeria: Adoption approaches. BSJ Agri, 4(2): 4751.

\section{Introduction}

Aquaculture in Nigeria enables man to culture his desired fish species. Other advantages of aquaculture include the utilization of vast available untapped land and water resources that abound in swamps and burrow pits, reduction of pressure on fishing in natural waters, ease of getting fish from a pond relative to catching fish from the river, obtain healthier fish relatively free of pesticides and additional harmful toxicants, and the control of fish growth through supplementary feeding (Agbamu and Orhorhoro, 2007)

The economic status, age, scale of production, education level, cosmopolitans and socio-cultural situation of farmers are possible factors that could affect adoption of innovations. The rate of adoption of innovations differs greatly according to place and circumstances of farmers (FAO, 2011). Water management plays a vital role in fish farming. To help the fish farmer better understand the properties of water as they affect fish culture. These properties include: physical characteristics of water, water balance in fish, sources of water, water quality, water physical and factors and chemical factors (Singh, 2007).

Following the dissemination of information on assistance to aquaculture technologies by the Delta State
Agricultural and Rural Development Agency (DARDA) over a decade ago, through farm inputs and assets supports, the provision of loans for aquaculture development in Delta State and the activities of nongovernmental organizations on fisheries extension which have created awareness on aquaculture technologies, it has become necessary to examine the level of adoption of aquaculture management techniques in the state (MANR, 2017).

There are needs to assess the functionality and success of the existing aquaculture business whether Nigerians are satisfied with the currently available or usable techniques. If farmers seem satisfied with their own technique, then there is need to evaluate their annual yield in relation to technological inputs. If maximum productivity is not attained then there is need for a change and this change will have to go with the farmers' willingness to adopt the technology brought before them (Donye et al., 2008).

Why technology adoption in aquaculture? It has been observed that, there is low level of production, poor storage facilities, lack of awareness of rural farmers, low adoption rate of this farmers to new techniques and inconsistent trade policies have been found to be responsible for the insufficient market supply of 


\section{Black Sea Journal of Agriculture}

aquaculture products (Akindele and Alabi, 2010).

Land and Location has to be considered first because most villages in Oshimili South LGA are distant from the natural water source and thus farmers in this region have to create their own water source by sinking boreholes or channel water from nearby river and land is quite expensive for local fish farmers (Palash, 2015). In addressing these gaps, this study was proposed and was achieved by some set objectives.

The objectives were as follows to:

I. Describe the socio-economic characteristics of the farmers.

II. Ascertain the level of adoption of aquaculture management techniques.

III. Determine the types of pond contributing to aquacultural techniques adoption.

IV. Assess the needs of fish farmers on new fishing techniques.

V. Identify the constraints affecting the adoption of aquaculture management techniques.

\section{Material and Methods}

The study was conducted in Oshimili South Local Government Area of Delta State. Delta State is located in the coordinates of latitude $6^{\circ} 34^{\prime}-645^{\prime} \mathrm{E}$ and longitude 559' - 608'N (MLSUD, 2013).

Sample Size and Sampling Technique: A pre-field survey revealed that there were registered fish farmers in Oshimili South Local Government Area which were found in Asaba, Okwe and Oko (Table 1). A quota sampling technique was used to select $50 \%$ of registered fish farmers. This resulted in a sample size of 82 fish farmers.

Table 1. Selection of respondents from workers*

\begin{tabular}{ccc}
\hline $\begin{array}{l}\text { Fish farm } \\
\text { communities } \\
\text { (Stage 1) }\end{array}$ & $\begin{array}{c}\text { Registered } \\
\text { fish farmers } \\
\text { (Stage 2) }\end{array}$ & $\begin{array}{c}\text { Selection of } \\
\text { respondents (50\%) } \\
\text { (Stage 3) }\end{array}$ \\
\hline Asaba & 95 & 47 \\
Okwe & 47 & 24 \\
Oko & 22 & 11 \\
\hline
\end{tabular}

*Delta State Agricultural Procurement Agency, Asaba

\subsection{Methods of Data Collection}

Data were collected by administering questionnaires.to the fisher folks and through field observations.

\subsection{Measurement of Variables}

Some socioeconomic variables such as ages, fish farming experience of respondents were measured in years. Education level options were made available for respondents to indicate as applicable: no formal education, primary or secondary school, OND/NCE, and HND/First Degree. Income generated was measured in the Naira amount as realized annually. Contact with extension agent was measured as applicable to weekly, monthly, quarterly, biannual or annual visits.

The scale used for measurement of the level of adoption of aquaculture management techniques was designed as positive (Yes) and negative (No). In order to standardize adoption scores, percentages obtained were translated to sigma score in the statistical Table of normal deviates (Ovharhe, 2020)

Factors that significantly contribute to adoption of the techniques were measured using location parameters such as Asaba, Okwe and Oko were listed alongside with selected technologies such as earthen pond, concrete pond, plastic pond and wooden pond for respondents to indicate as applicable.

The need assessments of fish farmers on new fishing techniques were measured on multiple response patterns. While constraints affecting adoption of aquaculture management techniques was measured by asking the respondents the level of seriousness of possible constraint affecting the adoption. This will be measured on a four (4) Likert-type scale of very serious $=4$, serious $=3$, not very serious $=2$, not serious $=1$. The mean value is $2.50(4+3+2+1=10 / 4=2.5)$ was used as a cut-off point such that constraints with mean value of 2.50 and above will be regarded as serious and vice versa. However, the percentage scores and means from the Likert-type scale computation were used for results interpretation.

\subsection{Ethical Consideration}

The study was approved by Delta State University local ethics committee with the number S177/029.

\section{Results and Discussion}

The result in Table 2 shows that mean age of the respondents was 44. This is in agreement with the findings of Agbamu and Orhorhoro (2007) on the adoption of aquaculture management techniques in Delta State. Male respondents (83\%) were more in participation. These findings are not agreement with the findings of Nwabueze, (2010) who reported that women were more than men in sustainable aquaculture development in Delta State. Respondents (65\%), were married. This aligned with the findings of Okoedo-Okojie and Ovharhe, (2012) on assessment of information needs of fish farmers in Delta State that most farmers were married. Majority of respondents (44\%) had HND/ First Degree as educational attainment. These results show that majority of the respondents had formal education and are literates which are in agreement with the findings of Ofuoku et al. (2008) and Ovharhe (2019) on the determinants of adoption of improved fish production technologies in Delta State.

Respondents (44\%) farming experience mean was 7 years. This is in disagreement with the findings of Agbamu and Orhorhoro (2007) on adoption of aquaculture management techniques in Delta State that the mean farming experience was 10 years. On average, respondents (56.1\%) household size was 5 persons; this is in agreement with the findings of Ifejike et al (2013) on emerging income-generating of fisher folks in riverine communities of Delta State whose results showed a mean household size of 5 persons. Respondents (49\%) annual 
mean income size was $125,277.14$, which is in agreement with the findings of Ovharhe (2016) on income generation of fish farmers in Delta State discovered that farmers earned between 35,000 and 135,000 Naira only annually on small scale basis. Respondents (92\%) got annual extension visit. These poor findings were reported by Ovharhe and Gbigbi (2016) on socioeconomic determinants of youth empowerment by Fadama III projects in Delta State.

Table 2. Respondents' socio economic profile $(n=82)^{*}$

\begin{tabular}{|c|c|c|c|}
\hline Variables & Frequency & Percentages (\%) & Mean/Mode \\
\hline \multicolumn{4}{|l|}{ Age } \\
\hline 21-30 & 9 & 11 & \multirow{4}{*}{44} \\
\hline $31-40$ & 13 & 16 & \\
\hline $41-50$ & 45 & 55 & \\
\hline $51-60$ & 15 & 18 & \\
\hline \multicolumn{4}{|l|}{ Gender } \\
\hline Male & 68 & 83 & \\
\hline Female & 14 & 17 & \\
\hline \multicolumn{4}{|l|}{ Marital status } \\
\hline Single & 28 & 34.1 & \multirow{3}{*}{ Married } \\
\hline Married & 53 & 65 & \\
\hline Separated & 1 & 1.2 & \\
\hline \multicolumn{4}{|l|}{ Educational status } \\
\hline Primary & 3 & 4 & \multirow{5}{*}{ HND/First Degree } \\
\hline Secondary & 17 & 21 & \\
\hline $\mathrm{OND} / \mathrm{NCE}$ & 21 & 26 & \\
\hline HND/ First Degree & 36 & 44 & \\
\hline Post graduate & 5 & 6.1 & \\
\hline \multicolumn{4}{|l|}{ Farming Experience } \\
\hline $1-5$ & 29 & 35.4 & \multirow{6}{*}{7 years } \\
\hline $6-10$ & 36 & 44 & \\
\hline $11-15$ & 7 & 9 & \\
\hline $16-20$ & 6 & 7.3 & \\
\hline $21-25$ & 2 & 2.4 & \\
\hline $26-30$ & 2 & 2.4 & \\
\hline \multicolumn{4}{|l|}{ House Hold Size } \\
\hline $1-3$ & 33 & 40.2 & \multirow{3}{*}{5} \\
\hline $4-6$ & 46 & 56.1 & \\
\hline $7-9$ & 3 & 4 & \\
\hline \multicolumn{4}{|l|}{ Income/annum } \\
\hline $35,000-135,000$ & 40 & 49 & \multirow[t]{6}{*}{$125,277.14$} \\
\hline $136,000-236,000$ & 17 & 21 & \\
\hline $237,000-337,000$ & 16 & 20 & \\
\hline $338,000-438,000$ & 4 & 5 & \\
\hline $439,000-539,000$ & 3 & 4 & \\
\hline $540,000-640,000$ & 2 & 2.4 & \\
\hline \multicolumn{4}{|l|}{ Extension Contact } \\
\hline Monthly & 3 & 4 & \\
\hline Quarterly & 3 & 4 & \\
\hline Biannually & 1 & 1.2 & \\
\hline Annually & 75 & 92 & Annually \\
\hline
\end{tabular}

*Field responses

\subsection{Adoption of Aquaculture Management} Techniques

Entries in Table 3 show that respondents (78\%) adopted earthen pond technique while respondents (15.9\%) had the lowest adoption rate in integrated technique. This is not in agreement with the findings of Agbamu and Orhorhoro (2006) on the Adoption of Aquaculture Management Techniques in Delta State which followed that respondents adopted the integrated technique which enabled them to culture different fish species in the same pond. This sigma method was used by Ovharhe (2016) to assess the adoption level of Fish Farmers in the Niger Delta.
3.2. Pond Types Contributing to Aquacultural Techniques Adoption

Across the study area, data displayed in Table 4 shows that earthen pond (88\%) had the highest adoption rate followed by the plastic pond (79\%), concrete $(71 \%)$ and wooden ponds (59\%) respectively). This outcome is not in accordance with the findings of Okoedo-Okojie and Ovharhe (2012) who reported that fish farmers in Delta State practice more of plastic and concrete ponds than earthen ponds. Rouhani and Britz (2004) cautioned that adoption of pond types contributes to the success of any fish farming. 


\section{Black Sea Journal of Agriculture}

\subsection{Needs Assessment Techniques of Fish Farmers}

The data in Table 5 shows that integrated techniques $(90.2 \%)$ had the highest value whereas record keeping $(24.4 \%)$ had the lowest value. There is a need to supply farmers with affordable feed formulation techniques and training on how to keep farm records in order to boost the productivity of fish and to improve protein intake in Delta State and in Nigeria at large. This is in line with the findings of Ovharhe (2016) who asserted that farmers in Delta State need adequate funding.

Table 3. Respondents' adoption level of aquaculture management techniques $(n=82)^{*}$

\begin{tabular}{|c|c|c|c|c|c|c|}
\hline & Techniques & Yes & No & $\begin{array}{c}\text { Total number of adopters } \\
\text { and its } \%\end{array}$ & $\begin{array}{l}\text { Adoption } \\
\text { score }\end{array}$ & $\begin{array}{l}\text { Adoption } \\
\text { level }\end{array}$ \\
\hline 1 & Earthen pond & 64 & 18 & $64(78.0)$ & 5.4 & High \\
\hline 2 & Concrete pond & 34 & 48 & $34(41.5 \%)$ & 4.4 & Medium \\
\hline 3 & Plastic pond & 41 & 41 & $41(50 \%)$ & 4.7 & Medium \\
\hline 4 & Wooden pond & 21 & 61 & $21(25 \%)$ & 3.7 & Low \\
\hline 5 & $\begin{array}{l}\text { Pond treatment } \\
\text { technique }\end{array}$ & 61 & 21 & $61(74.4 \%)$ & 5.35 & High \\
\hline 6 & $\begin{array}{l}\text { Water treatment } \\
\text { technique }\end{array}$ & 59 & 23 & $59(71.95 \%)$ & 5.3 & High \\
\hline 7 & Feed formulation & 58 & 24 & $58(70.7)$ & 5.3 & High \\
\hline 8 & $\begin{array}{c}\text { Integrated technique } \\
\text { Overall mean } \\
\text { adoption level }\end{array}$ & 13 & 69 & 13 (15.9) & $\begin{array}{l}3.2 \\
5.0\end{array}$ & Low \\
\hline
\end{tabular}

*Field responses

Table 4. Respondents' perceptions on pond types contributing to adoption of the techniques (Multiple responses)*

\begin{tabular}{cccccc}
\hline & Parameter & Earthen pond & Concrete pond & Plastic pond & Wooden pond \\
\hline 1 & Asaba & $70(85.36 \%)$ & $57(69.51 \%)$ & $62(75.6 \%)$ & $57(69.51 \%)$ \\
2 & Okwe & $76(92.68 \%)$ & $65(79.26 \%)$ & $69(84.14 \%)$ & $65(79.26 \%)$ \\
3 & Oko & $71(86.58 \%)$ & $54(65.85 \%)$ & $64(78.0 \%)$ & $54(65.85 \%)$ \\
\hline & \% mean & 88 & 71 & 79 & 59 \\
\hline
\end{tabular}

*Field responses

Table 5. Respondents' needs assessment (Multiple responses)*

\begin{tabular}{lccc}
\hline & Parameters & Frequency & Percentage (\%) \\
\hline 1 & Integrated techniques & 74 & 90.2 \\
2 & Pond preparation & 64 & 78.1 \\
3 & Storage & 54 & 65.9 \\
4 & Feed formulation & 52 & 63.4 \\
5 & Spawning & 45 & 54.9 \\
6 & Land & 30 & 36.6 \\
7 & Water source & 25 & 30.5 \\
8 & Market stategies & 27 & 32.9 \\
9 & Equipment & 22 & 26.8 \\
10 & Record keeping & 20 & 24.4 \\
\hline
\end{tabular}

*Field responses

3.4. Constraints Affecting Adoption of Aquaculture Management Techniques

Result in Table 6 shows that high feed cost with the highest percentage of $80.5 \%$ and a mean of 3.06 above the cut-off mean of 2.5 is the most serious constraint militating against adoption while poaching with the lowest percentage of $20.73 \%$ and a mean of 1.37 below the cut off mean of 2.5 is the least constraint. This assertion corroborates with that of Anene et al (2010) who reported that poor funding is the major constraint affecting the adoption of aquaculture techniques hence insufficient funds to handle the high cost of foreign feeds feed purchased. Therefore, farmers should be trained on how to formulate feed to supplement the exotic feeds. However, the pooled mean 2.40, which depict a management situation that the constraints are generally below average in theory and can be easily managed not to hamper fish farming adoption practices in agricultural productivity. 
Black Sea Journal of Agriculture

Table 6. Respondents' constraint militating against adoption $(n=82)$

\begin{tabular}{lcccc}
\hline & Parameter & *Percentage (\%) & *Mean & Remark \\
\hline 1 & High feed cost & 80.5 & 3.06 & Serious \\
2 & High take off fund & 75.6 & 2.89 & Serious \\
3 & Insufficient knowledge & 65.8 & 2.78 & Serious \\
4 & Scarcity of feed & 47.5 & 2.57 & Serious \\
5 & Costly technique & 43.9 & 2.56 & Serious \\
6 & Labor cost & 36.6 & 2.39 & Not serious \\
7 & Transportation & 24.3 & 1.54 & Not serious \\
8 & Poaching & 20.73 & 1.37 & Not serious \\
\hline
\end{tabular}

*Implies values from Likert-type scale converted to $\%$ and means. Cut off mean $=2.5$.

\section{Conclusion}

The study was guided by five objectives. Results obtained, besides the socio-economic characteristics, revealed that majority of fish farmers adopted earthen pond management techniques than plastic, concrete and wooden pond. Pond types contributed to aquacultural techniques adoption. The most prioritized need on assessment scale was integrated techniques and high cost of feeds was the most serious constraint. It was concluded that despite the prevailing constraints, there was a high adoption rate of aquacultural techniques among fish farmers in Oshimili South LGA of Delta State, Nigeria.

Based on the findings of the study, it is recommended that more awareness should be created among youths to increase participation in aquaculture, extension visit should be monthly and training on integrated techniques, feed formulation amongst others are needed.

\section{Author Contributions}

OJO; project supervisor, ON; fish expert and manuscript vetting, VO; data collection and analysis. All authors reviewed and approved the manuscript.

\section{Conflict of Interest}

The authors declare that there is no conflict of interest.

\section{References}

Agbamu JU, Orhorhoro WC. 2007. Adoption of aquaculture management techniques in Delta State. Nigeria J Food Agri Environ, 5(2): 243-246.

Akindele LA, Alabi OE. 2010. Use of information communication technologies. ICTs among fish farmers in Oyo State. J Agri Extens, 14(1): 4-12.

Anene A, Ezeh CI, Oputa C0. 2010. Resources use and efficiency of artisanal fishing in Oguta, Imo State, Nigeria. J Dev Agri Econ, 2: 94-99.

Donye AO, Usman IS, Nuhu HS, Ogunbameru BO, Mustapha SB. 2011. Assessment of women participation in fish farming in Maiduguri Metropolis, Borno State, Nigeria. J Agri Sci, 1: 6-13. FAO. 2011. Food and Agriculture Organization, Fishery and aquaculture country profiles Nigeria. Fisheries and Aquaculture Department, http://www.fao.org/fishery/countrysector/FI-CP_NG/3/en (accessed date: December 01, 2020).

Ifejika PI, Belonwu EN, Malagwi YY, Odunuga AO, Mbah AA. 2013. Emerging income generating activities of fisher folks $n$ riverine communities of Niger State, Nigeria. J Fisheries Aquatic Sci, 8(6): 706-713.

MANR. 2017. Delta State ministry of agriculture and natural resources, annual report.

MLSUD. 2013. Ministry of lands, survey and urban development. The Delta State Coordinate.

Nwabueze AA. 2010. The role of women in sustainable aquacultural development in Delta State. J Sustainable Develop Africa, 12: 284-293.

Ofuoku AU, Enakle M, Nnodim AU. 2008. Cohesiveness of fish farmers groups in Southern Nigeria. J Agri Biol Sci, 3(4): 1621.

Ofuoku AU, Olele NF, Emuh GN. 2008. Determinants of adoption of improved fish production technologies among fish farmers in Delta State, Nigeria. J Agri Edu Exten, 14(4): 297-306.

Okoedo-Okojie DU, Ovharhe JO. 2012. Assessment of information needs of fish farmers in Delta State, Nigeria. Nigerian J Agri Food Environ, 8(3): 72-77.

Ovharhe OJ, Gbigbi MT. 2016. Socio-economic determinants of youth empowerment by fadama III project in Delta State, Nigeria: Implications for agricultural transformation. Inter J Agri Extension Rural Develop Stud, 3(1): 12-20.

Ovharhe OJ. 2016. Aquaculture technologies adoption by Fadama III aquaculture farmers in Niger Delta. J Northeast Agri Univ, 23(4): 78-81.

Ovharhe 0J. 2019. Determinants of the socioeconomic profile of fadama III project beneficiaries in three states of Niger Delta Area of Nigeria. Inter J Agri Sci, 4: 29 - 34.

Ovharhe 0J. 2020. Poultry technologies adoption by farmers in the Niger Delta Area of Nigeria. FUW Trends Sci Technol J, 5(3): 813-815.

Palash S, Hunayun K, Bauer S. 2015. Fish farming land allocation in Northern Part of Bangladesh: Exploring Causes across the farm size. World J Agri Res, 3(6): 208-217.

Rouhani QA, Britz PJ. 2004. Contribution of aquaculture to rural livelihoods in South Africa: A Baseline Study. Water Research Commission, Gezina, 1st Edition, pp: 105-107.

Singh AP. 2007. Water quality management. J Water Res Manage, 21(2): 525-532. 